\section{Residual Efficacy of Uniconazole and Daminozide on Potted 'Bright Golden Anne' Chrysanthemum}

\author{
Harry K. Tayama ${ }^{1}$ and Stephen A. Carver ${ }^{2}$ \\ Department of Horticulture, The Ohio State University, 2001 Fyffe \\ Court, Columbus, OH 43210
}

Additional Index words. Dendranthema ×grandiflorum, Sumagic, B-Nine, XE-1019

\begin{abstract}
Residual activity of a single uniconazole spray (15 mg a.i./liter), uniconazole drench (600 $\mu \mathrm{g}$ a.i./pot), and daminozide spray $(5000 \mathrm{mg}$ a.i./liter) were compared to an untreated control using the 'Bright Golden Anne' chrysanthemum [Dendranthema grandiflorum (Ramat.) Kitamura]. Based on weekly internode growth, spray and drench treatments with daminozide and uniconazole remained active for 2 to 2.5 and 3 to 3.5 weeks, respectively. Chemical names used: butanedioic acid mono (2,2-dimethylhydrazide) (daminozide); (E)-1-(p-chlorophenyl)-4,4-diemethyl 1-2(1,2,4-triazol-2-yl)-l-penten-3-01 (uniconazole).
\end{abstract}

Uniconazole is a relatively new, potent, but as of yet unregistered plant growth regulator (PGR). Davis et al. (1988) noted that triazoles, the class of PGRs to which uniconazole belongs, are more effective at lower concentrations than others, such as daminozide and chlormequat chloride. A single spray of uniconazole at $20 \mathrm{mg}$ a.i./liter applied to diverse species of flowers and a single $6.25 \mathrm{mg}$ a.i./liter spray applied to Cathranthus roseus were as effective or more so than two $5000 \mathrm{mg}$ a.i./liter daminozide spray applications (Barrett and Nell, 1986, 1987). Uniconazole at 15 or $20 \mathrm{mg}$ a.i./liter caused a retardation similar to chlormequat chloride at $3500 \mathrm{mg}$ a.i./liter on dwarf potgrown carnation (Dianthus calyophyllus L.) (Pobudkiewicz and Goldsberry, 1989). A single uniconazole spray at $20 \mathrm{mg}$ a.i./liter or two sprays at $10 \mathrm{mg}$ a.i./liter provided control equivalent to two daminozide sprays at $2500 \mathrm{mg}$ a.i./liter on potted chrysanthemum cultivars Puritan and Favor (Starman, 1990). Unspecified chrysanthemum cultivars treated with a single spray application of uniconazole at $10 \mathrm{mg}$ a.i./liter were similar in height to plants sprayed three times with daminozide at $2500 \mathrm{mg}$ a.i./liter (Wilfret, 1988). These studies attest to the potency of

Received for publication 28 Mar. 1991. Accepted for publication 28 Aug. 1991. Salaries and research support provided by state and federal funds appropriated to The Ohio State Univ., Ohio Agricultural Research and Development Center, Columbus. We gratefully acknowledge Yoder Brothers, Barberton, Ohio, for donation of chry santhemum cuttings and Grace/Sierra and Co., Fogelsville, Pa., for donation of Metro-Mix 350. Trade names are used to provide specific information. Mention of a trade name does not constitute a guarantee of the product or an endorsement by the U.S. Dept. of Agriculture over other products not mentioned. The cost of publishing this paper was defrayed in part by the payment of page charges. Under postal regulations, this paper therefore must be hereby marked advertisement solely to indicate this fact.

'Professor.

${ }^{2}$ Research Associate.

- Control night minimum of $17 \mathrm{C}$ on 21 Mar. Throughout the study, plants were maintained under long-day conditions (incandescent light 10:00 PM to 1:00 AM). Single spray or drench PGR treatments were applied when roots reached the sides and bottom of the pot and 2 to $4 \mathrm{~cm}$ of new stem growth was evident (30 Mar.). Sprays were applied at $204 \mathrm{ml} \cdot \mathrm{m}^{-2}$ of bench area, or $\approx 3 \mathrm{ml} / \mathrm{plant}$. The drench was applied as $120 \mathrm{ml}$ of solution per 1.2-liter pot. Plant measurements taken initially and weekly thereafter for 5 weeks were height above the pot rim, internode number (counting from the base of the plant to the internode nearest the terminal that was at least $1 \mathrm{~cm}$ long), and length of each internode. The length of the four apical internodes was averaged for data analyses and presentation. The study was terminated at' the end of the 5th week because crown buds were visible. There were four treatments: untreated control, daminozide spray at $5000 \mathrm{mg}$ a.i./liter ( $\approx 15 \mathrm{mg}$ a.i./plant), uniconazole drench at 600 $\mu \mathrm{g}$ a.i./pot, and uniconazole spray at $15 \mathrm{mg}$ a.i./liter $(\approx 45 \mu \mathrm{g}$ a.i./plant). Each treatment was replicated three times (i.e., three samples or statistical observations) with six plants (subsamples) per replicate. This yielded a mixed two-factor design-treatment $\times($ time $\times$ rep $)$ with treatment as the "between-measures" factor and time as the "within-measures" or repeated-measures factor. In addition to analysis of variance, omega squared was calculated for the main and interaction effects to provide a measure of the proportion of the total variance attributable to each effect. Finally, LSD values $(\mathrm{P}=0.05)$ based on significant interactions were calculated to allow mean comparisons.

The study was repeated beginning 28 Mar., and again 11 Apr. The results of the second and third trials were the same through week 4 as those obtained in the first trial. Crown bud development became evident at that point so studies were then terminated. Conse-

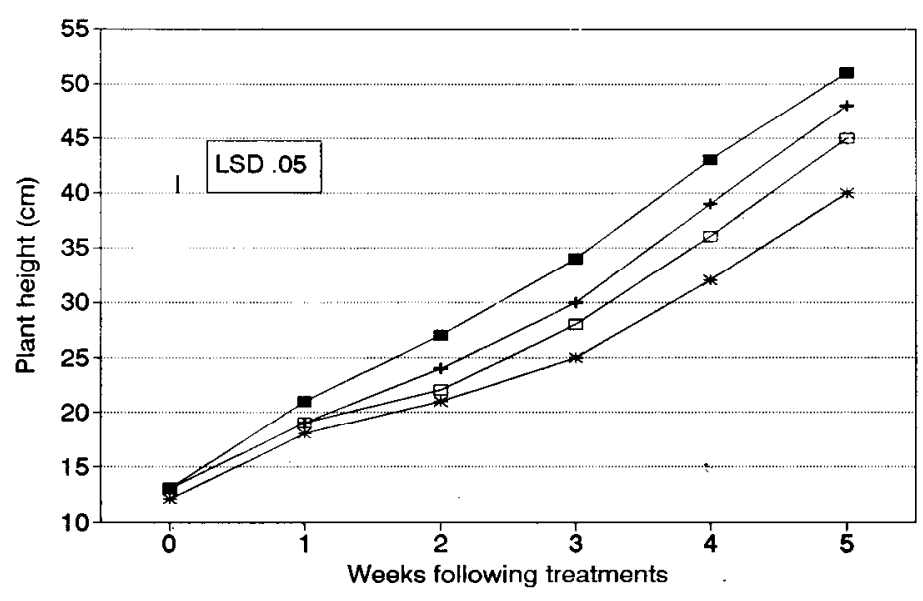
- Damin. spray $*$ Unic. drench $\sqsubset-$ Unic. spray

Fig. 1. Change in total plant height of 'Bright Golden Anne' chrysanthemum treated with growth regulators. The $\mathrm{F}$ test yielded a significance level for each main effect and the interaction at $\mathrm{P}=$ 0.001 . Omega squared values (a measure of the proportion of the total variance attributable to the main and interaction effects) for each effect were as follows: treatment $=0.041$, time $=0.938$, and interaction $=0.015$. The $\mathrm{LSD}_{0.05}$ value for the interaction is 1.51 . Plants were treated week 0 . 


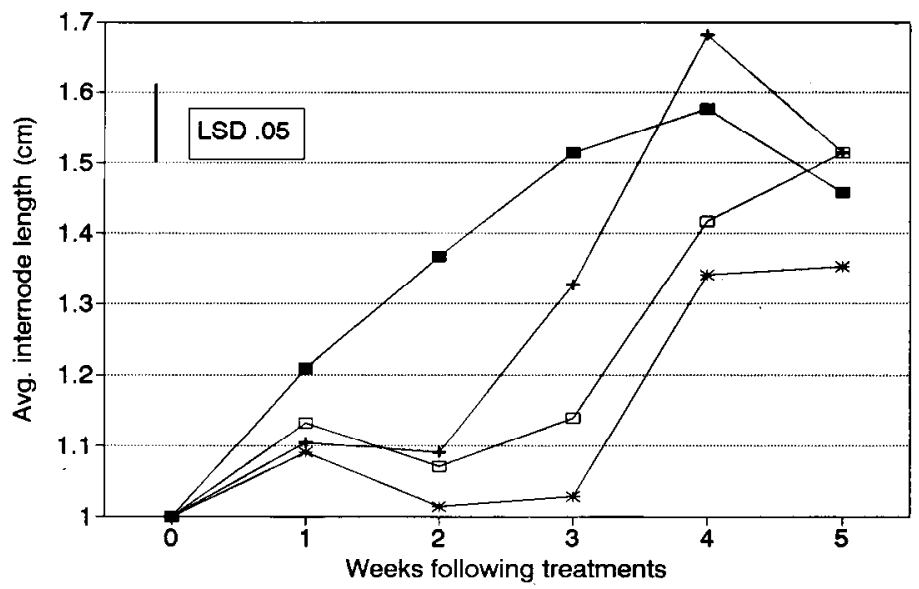

- Control

+- Damin. spray * Unic. drench $\sqsubset-$ Unic. spray

Fig. 2. Average lengths of the four apical internodes $\left[\left(\right.\right.$ Internode,$+\ldots+$ Internode $\left.\left._{4}\right) / 4\right]$ of 'Bright Golden Anne' chrysanthemum treated with growth regulators. The F test yielded a significance level for each main effect and the interaction at $P=0.001$. Omega squared values for each effect were as follows: treatment $=0.213$, time $=0.569$, and interaction $=0.117$. The $\operatorname{LSD}_{0.05}$ value for the interaction is 0.11 .

quently, only results from the first trial are presented.

Significant PGR treatment and interaction effects for plant height revealed that single PGR applications effectively, but differentially, retard stem elongation. All plants were essentially the same height at the beginning of the study but elongated at different rates in response to PGR activity. At the conclusion of the study, all PGR-treated plants (Fig. 1) were shorter than control plants, with uniconazole-drenched plants exhibiting the most profound growth retardation (22\%), followed by those sprayed with uniconazole $(12 \%)$ or daminozide $(5 \%)$.

Plants averaged between four and five new internodes per week. An average length of the four apical internodes, therefore, provided a relative measure of PGR efficacy from week to week. Average internode length among the three PGR treatments remained similar during the first 2 weeks following application (Fig. 2). By the end of the 3rd week, however, they were evident. Terminal internodes of daminozide-treated plants, though shorter than those of control plants, were significantly longer than internodes of daminozide-treated plants of the previous week. Clearly, daminozide lost efficacy in this study between weeks 2 and 3. There was no difference in average internode length between weeks 2 and 3 for either uniconazole treatment, and plants in both were shorter than those treated with daminozide. During week 4, efficacy of uniconazole spray and drench treatments weakened. Terminal internodes of plants from both uniconazole treatments were significantly longer than those of the previous week, although both were shorter than the control. At the end of the final week, none of the PGR treatments differed significantly from the control.

There was a significant difference in the number of internodes among treatments (results not shown). However, this was not interpreted to indicate that PGR treatments reduced the number of nodes produced. Although the treatment effect was significant, it contributed $<1 \%$ of the total variance observed in internode number compared to
$>98 \%$ for the time effect. The data reflect a count of internodes that were $1 \mathrm{~cm}$ or longer. Internodes at and subtending the stem apices were shorter than $1 \mathrm{~cm}$ and therefore were not counted. Rather than reduce the number of internodes, PGR treatments slowed the rate of elongation of the young apical internodes, thereby reducing the number of internodes counted.

In this study, daminozide and uniconazole provided similar initial control of stem elongation. A single daminozide spray at $5000 \mathrm{mg}$ a.i./liter effectively limited internode elongation of BGA chrysanthemum for 2 to 2.5 weeks, and uniconazole spray (15 mg a.i./liter) and drench $(600 \mathrm{~kg}$ a.i./pot) treatments for 3 to 3.5 weeks. Uniconazole spray and drench treatments do have the potential of providing longer residual activity from a single application than daminozide. Differences in cultivar sensitivity need to be evaluated. Wilfret (1988) reported that chrysanthemum cultivars Circus, Fiesta, and Cirbronze were sensitive to a single application of uniconazole at $10 \mathrm{mg}$ a.i./ liter, while 'Stoplight' required $60 \mathrm{mg}$ a.i./ liter. It appears that as relative cultivar sensitivity to uniconazole varies, residual efficacy may change.

\section{Literature Cited}

Barrett, J.E. and T.A. Nell. 1986. Evaluation of XE-1019 and paclobutrazol for height control of flowering annuals. Proc. Plant Growth Regulat. Soc. Amer. 13:62-64.

Barrett, J.E. and T.A. Nell. 1987. Efficacy and phytotoxicity of paclobutrazol and XE-1019 on vinca. Proc. Fla. State Hort. 100:382-383.

Davis, T.D., G.L. Steffens, and N. Sankhla. 1988 Triazole plant growth regulators. Hort. Rev. 10:63-105.

Pobudkiewicz, A.K. and K.L. Goldsberry. 1989. Response of dwarf carnation 'Snowmass' to growth retardant application. Colorado Greenhouse Growers Res. Bul. 468.

Starman, T.W. 1990. Whole-plant response of chrysanthemum to uniconazole foliar sprays or medium drenches. HortScience 25:935-937.

Wilfret, G.J. 1988. Effect of XE-1019 on height of containerized chrysanthemums. ASHS/CSHS 1988 Annu. Mtg., East Lansing, Mich., Prog. \& Abstr. HortScience 23:819[163]. 